\title{
Modernisme dan Fundamentalisme sebagai Fenomena Gerakan Keagamaan dalam Sosial Masyarakat
}

\author{
Mohammad Asrori Alfa* \\ Dosen Fakultas Humaniora dan Budaya Universitas Islam Negeri (UIN) Malang
}

\begin{abstract}
Many issues on "Modernism" and "Fundamentalism" prove the development of ideologies and sects as religious, social, and politic phenomena existing in society. Nevertheless, this study aims to focus on the religious phenomenaonly because each of the ideologies and sects cannot be separated from its historical root that is related much to the problems of Christian development in western countries. Furthermore, this study results from intellectual exploration that is able to find out and sketch the characteristics of "Modernism" and "Fundamentalism" as religious phenomena existing in society. As a result, it can finally distinguish the typology of social communities that include in the category of each ideology. Moreover, it explains that that various performances of religious movements in society can be included in the typology of each ideology.
\end{abstract}

Keywords: modernism, fundamentalism

\section{A. Pendahuluan}

Isu-isu besar (grand issues) modernisme dan fundamentalisme merupakan dua hal kategori fonomena yang bertolak belakang di permukaan. Pemahaman dua istilah tersebut dapat dijumpai di berbagai masyarakat yang menganut "agama-agama dunia", sebagaimana Yahudi, Hindu, Kristen, dan Islam (Yusril Ihza Mahendra, 1999: 3). Kenyataannya, dua fenomena di atas dapat melahirkan inspirasi penulis yang merupakan sinyal-sinyal sebagai suatu fenomena keagamaan.

Perkembangan berbagai fenomena terakhir di permukaan, dapat dikatakan sebagai suatu pergeseran pemikiran yang signifikan, apabila "Modernisme" dan "Fundamentalisme" yang dikorelasikan dengan "agama" 
dapat pula digunakan sebagai suatu fenomena keagamaan, sosial, budaya, dan politik (Yusril Ihza Mahendra, 1999: 3). Persoalannya sekarang adalah: apa karakteristik modernisme dan Fundamentalisme itu? bagaimana korelasi Fndamentalisme dengan orientasi idiologi Modernisme dalam gerakan social masyarakat?

Bertolak dari minimal pertanyaan di atas, penulis ingin mencoba menarik dua aliran tersebut sebagai fenomena keagamaan dalam social masyarakat. Karena demikian, sesungguhnya dalam fenomena keagamaan secara umum apabila dianalisa secara mendalam, maka akan memunculkan polarisasi dua aliran atau bahkan idiologi "Modernisme" maupun "Fundamentalisme" dalam konteks kajian ini.

Memahami dan menganalisa pokok kajian ini, barang kali untuk lebih mudah mengawalinya perlu terlebih dahulu menjelaskan tiga pengertian dua aliran tersebut dalam Chapther I "The Making Of A Constnuct Modemism and Fundamentalism" sebagaimana berikut (Bruce B. Lawrence, 1989: 27):

"Fundamentalism is the affirmation of religious authority as holistic and absolute, admitting of naither criticism norreduction, it is expresesed through the collective demand that specific creedal and ethical dictates derived from scripture be publicly recognized and legally enforced"

(Artinya: Fundamentalisme adalah penegasan kekuatan atau otoritas keagamaan yang holistik dan absolut tanpa pengurangan dan kritikan. Hal ini diekspresikan lewat tuntutan kolektif bahwa keyakinan spesifik yang secara jelas terungkap dan berasal dari al-Qur'an harus diketahui secara luas dan dilaksanakan secara legal)

"Modernity is the emergence of a new index of human life shaped, above all, by I creasing bureaucratization and rationalization as well as tehnical capacities and global excange unthinkable in the premodren era"

(Artinya: Modernitas adalah munculnya indek baru kehidupan manusia yang dibentuk dengan cara meningkatkan birokratisasi dan rasionalisasi beserta kapasitas teknis pertukaran global yang belum pernah terpikirkan pada zaman sebelum modren dulu)

"Modernis is thesearch for individual autonomy driven by a set of socially encoded values emphasizing change over continuity, quantity over quality, efficient production, power, and profit over sympathy for traditional values or vocations one economic strategy, consumer-oriented capitalism, 
as the surest means the tehnological progress that will also eliminate social unrest and physical discomfort"

(Artinya: Modernisme adalah pencarian otonomi indivindu yang dipicu - leh serangkaian nilai-nilai yang tertanam dalam sesial yang selalu menuntut perubahan terus menerus, kuantitas diatas kualitas, produksi efisien, power, keuntungan atau profit dengan cara berimpati pada nilainilai, dan pekerjaan tradisional baik dari sektor publik maupun swasta. Pada tingkat ekstrem-nya, pada masa ini menobatkan satu strategi ekonomi, kapitalisme yang berorientasi pada konsumerisme sebagai sarana atau alat yang sangat pasti menuju progresitas teknologi yang secara otomatis juga akan mengileminir kegelisahan sosial dan ketidak-nyamanan)

Dari berbagai istilah tersebut, sesungguhnya dapat dijadikan modal untuk memahami subtansi pengkajian pada sub berikutnya.

\section{B. Subtansi Pembahasan}

\section{Istilah Modernisme dan Fundamentalisme: Sebuah Asal Usul}

Modernisme dan Fundamentalisme merupakan dua istilah yang masih kontroversial dalam internal agama. Hal ini dapat dipertegas bahwa "Fundamentalisme" sebagai reaksi terhadap "Modernisme" dapat diperbincangkan apabila agama dipertimbangkan lagi melalui sifat dan skopenya dari pra-modern (Bruce B. Lawrence, 1989: 27). Sesungguhnya dua istilah tersebut, sumber aslinya bukanlah dari bahasa dari masyarakatmasyarakat muslim. Akan tetapi, ketika diadakan suatu pelacakan kata "Modernisme" dan 'Fundamentalisme" berasal dari para sarjana Barat dalam konteks sejarah keagamaan pada masyarakat mereka sendiri (Yusril Ihza Mahendra, 1999: 3). Awal Mula "Modernisme" berarti "sebagai aliran keagamaan yang melakukan penafsiran doktrin agama Kristen untuk menyesuaikan dengan perkembangan pemikiran modern" (The Ensiclopedia Americana: 1970). Selanjutnya "Fundamentalisme" berarti sebagai reaksi terhadap "Modernisme". Ia dianggap sebagai aliran yang berpegang teguh pada "fundamen" agama Kristen melalui penafsiran terhadap kitab suci agama itu secara rigid dan leteris (The Oxford English Dictiønary: 1988).

Berbagai istilah juga sering digunakan "Modernisme" dan "Fundamentalisme" dapat difragmentasikan sebagaimana berikut: 1) 
"Modernisme" sebagaimana hal-nya "reformism", "rewakening", "renaissance", dan "renewal" 2) "Fundamentalisme" sebagaimana hal-nya "revivalism", "militancy', "reassertion", "resurgence', "activism", dan "reconstructionism" (Hrair Dekmijian, 1985: 4). Penggunaan istilah-istilah sering pula dapat dijumpai tidak sama satu dengan yang lainnya, melainkan juga dalam konteks pendefinisiannya juga mengalami makna yang berbeda pula.

Dari pemaparan berikut, sebagaimana makna "Modernisme" dapat diartikan apa yang dikehendaki penulis dalam penganalisaan muatan subtansi pemahaman yang di fragmentasikan itu mau diarahkan ke target (tujuan) apa, konteks sosial dan historisitasnya bagaimana. Dengan demikian, penggunaan kata "Modernisme" itu pula juga bergantung dengan penulisnya (pelaku). Meminjam istilah kata "Modernisme" dalam pandangan Maryam Jameelah adalah sebagai pembrontakan radikal dalam melawan agama serta nilai-nilai spiritual yang terkandung di dalamnya (Maryam Jameelah dkk.,1977: 39). Pernyataan ini, memiliki suatu penilaian yang cukup kurang obyektif-metodologis dan kecurigaan yang berlebihan, bahkan ia adalah salah satu sebagai tokoh fundamentalis yang telah menuduh tokoh-tokoh modernis sebagaimana Jamaludin al-Afghany, Muhammad Abduh, dan Sayyid Akhmad Khan sebagai "agen imperalis Barat" (Maryam Jameelah dkk., 1977: 55). Demikian pula "Modernisme" dalam pandangan Muhammad 'Abid al-Jabiry secara subtansi dikemukakan sebagai pembrontakan masa lampau, yang terdiri masa lalu dan masa kini, guna meciptakan sebentuk tradisi baru (Hasan Hanafi, dan Muhammad "Abid al-Jabiri, 2003: 113). Al-Jabiry dalam memberikan pemaknaan "Modernisme " tersebut, sebagai modernisme agresif total yang tidak terbatas dalam satu wilayah geografis di permukaan. Jadi menurut beliau bahwa kita harus menentang tradisi yang ada dan meleburkan diri secara total dalam sebuah peradapan kontemporer sedemikian rupa, sehingga seolaholah kita tidak memiliki tradisi. Artinya, hal ini dapat diupayakan tercapai dengan menggunakan resistemisasi atas tradisi kita, dan rekonstruksi hubungan kita dengannya dalam bentuk modren(Hasan Hanafi, dan Muhammad 'Abid al-Jabiri, 2003: 114). Selanjutnya, bandingkan dengan konsep "Modernisme" dalam pandangan Hasan Hanafi yang bermakna 
metaforis. Maksudnya, ia mengikuti berbagai style zaman dan beragam metodologinya dalam menghadapi al-thurats, yang merupakan style dari luar dan berdasarkan atas al-thurats yang mendukung keberadaan al-hadatsah (modernisme). Dengan demikian,"Modernisme" tidak harus bermakna Barat. Sesungguhnya, ia berarti kemampuan sebuah al-thurats untuk melakukan ijtihad agar mampu menyesuaikan diri dengan berbagai situasi setiap zaman(Hasan Hanafi, dan Muhammad 'Abid al-Jabiri, 2003: 116). Pada dasarnya, kekaburan kata "Modernisme" adalah kesalahan dalam memhami al-thurats sebagai al-taqlid saja, akan tetapi tidaklah mencoba untuk memhami al-thurats sebagai al-tajdid. Dengan demikian menurut Hasan Hanafi, bahwa kata al-thurats wa al-tajdid lebih relevan dari pada altaqlid wa al-hadatsah (Hasan Hanafi, dan Muhammad 'Abid al-Jabiri, 2003: 113).

Selanjutnya, Sebagaian kelompok modernis sebagaimana hal-nya Fazlur Rahman menyebutkan istilah "Fundamentalisme" dengan nada dan berbau sinisme bahwa kelompok fundamentalis sebagai "orang-orang yang dangkal dan superfisial", "anti intelektual, dan "pemikirannya tidak bersumberkan kepada al-Qur'an dan budaya intelektual tradisional Islam" (Fazlur rahman, 1979: 164). Hal ini lain lagi menurut pandangan R. Garaudy, yang menandaskan bahwa, "fundamentalisme" adalah suatu pandangan yang ditegakkan atas keyakinan, baik yang bersifat agama, politik, dan budaya yang dianut pendiri yang menanamkan ajaran-ajarannya di masa lalu dalam sejarah (R. Gharaudy, 1993; vii). Meskipun demikian, dibalik pendefisinian yang dikemukakan, apabila dianalisa secara mendalam maka masih terdapat berbagai konotasi yang negatif sebagaimana: absolutisme, eksklusifisme, fanatisme, agresivisme. Selanjutnya, berbeda pula kelompok Neo-Modernisme seperti Nur Cholis Majid, yang mengemukakan bahwa, istilah "Fundamentalisme" muncul setelah agama-agama yang terorganisasi (orgaized religions) gagal memberikan respon yang memadai terhadap tantangan dunia modren, di samping itu menurutnya, ia juga menyebarkan faham keagamaan yang telah baku, dan menyebarkan berbagai gagasan yang palsu dan bersifat menipu. Dalam konteks kekinian -masih menurutnya- bahwa Fundamentalisme telah menjadi "sumber kekacauan dan penyakit mental" yang baru dalam masyarakat. Sebagai 
akibat yang ditimbulkannya, jauh lebih buruk dibandingkan dengan masalah-masalah sosialyang sudah ada, seperti kecanduan minuman keras dan penyalahgunaan narkoba. (Nurcholis Majid, 1992: 586). Pernyataan tersebut, setidaknya dapat difahami bahwa di balik itu semua ternyata ada semacam kesan yang dapat membuat ketidaknyamanan dan penolakan dalam masyarakat.

\section{Modernisme: Kelahiran, Teori, dan Karakteristik}

Kelahiran modernisme itu pada abad 19, namun demikian, peristiwa itu tidak dapat dilepaspisahkan serangkaian abad-abad sebelumnya. Berangkat pemikiran dan pemahaman keagamaan yang paradoksal antara "puritanis-New England" dan "puritanis-protestan" yang dapat dijelaskan sebagaimanaberikut: kelompok pertama, berpedoman secara komprehenship terhadap Bible dan titik tekannya keyakinan (faith) dan kelompok kedua, ingin mencoba menggabungkan antara keyakinan (faith) dan pikiran (reason), sehingga yang terjadi dapat membuahkan kreatifitas dan saling melengkapi.

Perkembangan selanjutnya, muncul faham "Rasionalisme", akhirnya, puritanis-protestan memiliki dua alternatif kecenderungan. Ada yang tetap bertahan masuk evangelical-peitsm, ada pula yang masuk rasionalisme. Berikut juga patut di perhatikan bahwa evangelical-pietsm pernah menggeser dominasi rasionalisme dalam konteks sejarah tradisi keagamaan di Amirika (Robert Handy, 1955: 384). Peristiwa tersebut telah terjadi pada abad ke 18.

Selanjutnya, telah terjadi Perang sipil pada abad 19, yang sebagai awal munculnya "Modernisme" dalam hal pemikiran dan pola hidup. Akan tetapi masa sebelum perang tersebut, merupakan masa keimanan (age of faith), masa setelah perang merupakan masa kebingungan (age of doubt). Masa yang terakhir ini, banyak pastor mulai ragu akan kepastian yang ada pada bible. Sedangkan otoritas Bible dalam seluruh aspek kehidupan manusia mulai dipertanyakan (Robert Handy, 1955: 384).

Dari sini, pengaruh aliran pemikiran modren ini ternyata dapat mempengaruhi para menteri yang ingin mencoba mencari apologi baru untuk keyakinan (apology of faith), di samping itu juga ingin mencoba 
mencari pola antara keyakinan warisan mereka dengan ilmu pengetahuan tersebut sehingga diterima masyarakat secara luas. Sehingga dengan demikian, muncul dari evangelical-protestanism menjadi evangelical-liberalism. Para pemimpin ini pada awal mulanya percaya terhadap Bible dan Kristus dalam hal keagamaan. Namun demikian, mereka juga mengekpresikan hal ini dengan ungkapan masa kini yang sesuai dengan konteks terkini pula.

Akhirnya, ketika kelompok leberal mencoba membuka dengan hadirnya gerakan-gerakan pengetahuan baru dan terkini, maka tampak jelas bahwa warisan ortodoksi protestan mulai lenyap. Keagamaan yang selalu tampak melekat mulai tampak mengecil seiring dengan berkembang pesatnya di tengah perkembangan dunia progresifitas ilmiah yang baru. Kelompok liberal ini, juga berani beranggapan untuk menginterpretasi kepercayaan eskatologis secara progresif dan dan pemikiran revolosioner, di samping Yesus juga akan datang diakhir zaman memperbaiki dunia ini (Robert Handy, 1955: 388).

Sebagai reaksi untuk membendung aliran kelompok liberal ini, maka lahirlah sebuah gerakan yang kembali pada pemahaman yang ortodox lagi, yang selanjutnya disebut konservatisme ketat (strick-conservatism).

Selanjutnya, teori yang dapat dipahami dalam modernisme adalah merupakan sesuatu yang tidak ada dalam tradisionalism (Bruce B. Lawrence, 1989: 39).

Ada urgensitas teori modernisme yang menjadikan acuan sentral pokok dalam memahami totalitas modernisme dengan pra-modernisme sebagaimana berikut: a). Kalkulasi (counting) b). Komperasi (comparing) c). Sistemitasisasi (systematizing) (Bruce B. Lawrence, 1989: 28).

Penjelasannya teori diatas, bahwa kalkulasi counting adalah kalkulasi matematis yang merupakan premis dasar semua pengetahuan termasuk dalam sisi kosmologis tradisi agama. Jadi, peranan pemikiran matematis (baca: analog matematis) sangat penting dalam memperoleh pengetahuan yang meyakinkan. Namun berbeda hal-nya dengan perhitungan yang secara implisit merupakan komparasi (comparing), yang dapat diartikan dengan cara membandingkan satu rangkaian dengan rangkaian yang lain untuk melakukan perbandingan. Selanjutnya, apabila kita menganalisa bentuk 
komparasi ini, maka akan dapat melahirkan suatu perbandingan di berbagai hal berupa sinonim maupun antonym pemikiran dialektis, di samping merupakan alat kekuatan didaktik yang digunakan dalam serangkaian data khususnya dalam konteks ilmu social. Bertolak dari counting dan cooperation dapat melahirkan systematizing yang berarti memperluas hitungan dalam jumlah yang tak terbatas, dan ia sangat ketergantungan dibalik tujuan itu. Tujuannya adalah berusaha penataan ulang keberagamaan secara holistic, menyalurkan keacakan menjadisuatu visual, merangkai kerangka yang jelas melalui sitem aplikatif dan cocok pada kelompok yang ada dan juga pada saat yang bersamaan membuat kelompok merasa bagaian dari kepentingannya. Sistem yang dimaksudkan merupakan symbol yang menggambarkan tatanan, alasan, fungsi, dan struktur. Selanjutnya sifat systematizing adalah untuk merangkum, mengurangi, dan meringkas lagi. Sedangkan analog matematis bukanlah merupakan hanya jumlah, melainkan symbol kompleksitas besar yang dapat dikurangi menjadi bentuk diatur (manageable) dan dimainkan oleh si penghitung (Bruce B. Lawrence, 1989: 31-32).

Terakhir, konsep "Modernisme" dapat dijelaskan melelui karakteristik yang dimiliki, sehingga karakteristik "Modernisme" yang sudah menjadi kajian, berikut penelitian oleh sejumlah sarjana terdahulu dapat dijadikan dasar konsep modernisme-modernisnya sebuah bentuk komonitas masyarakat kita. Karakteristik "Modernisme" yang dimaksudkan sebagaimana berikut: 1). Apologetik, artinya, merupakan ciri yang ditandai dengan sikap pembelaan terhadap Islam dari berbagai tantangan yang datang dari kaum kolonial dan misionaris Kristen, ataupun ada sebagaian yang mengatakan suatu upaya untuk menunjukkan keunggulan Islam atas peradaban Barat (Hamilton A. R. Gibb, 1977: 68). 2). Romantisme artinya, mengagungkan zaman awal sebagai zaman kegemilangan peradaban Islam di masa lampau. Pernyataan ini, ternyata dipertegas oleh W. C. Smith, bahwa kemunduran Islam, bukanlah disebabkan kesalahan doktrin agama itu, melainkan kesalahan penganut-penganutnya. Puncak kesalahan itu adalah karena kaum Muslim itu sendiri telah melupakan agamanya (Wilfred C. Smith, 1946: 12). 3). Keharusan ijtihad, artinya, penolakan terhadap sikap jumud (kebekuan berfikir) dan taqlid (mengikuti sesuatu tanpa 
pengertian) (Fazlur Rahman, 1982: 215-217). 4). Jalan tengah, artinya, merupakan di tengah berbagai kecenderungan ekstrim yang terdapat dalam agama-agama dan paham-paham lain (Nurcholis Majid, 1992: 585-586). 5). Pentafsiran ijma' Modemisme, artinya, suatu consensus bersama yang dapat mengikat dan menghapuskan ijma'-ijma' sebelumnya. Statement ini ternyata juga dipertegas tokoh-tokoh modernis lain sebagaimana Muhammad Iqbal, Ali Jinah sebagai demokrasi Islam (Leonard Binder, 1961: 78). 6). Penolakan nilai-nilai Transendental, artinya, berbagai nilai moral serta kebenaran adalah suatu yang relatif dan validitasnya terbatas pada orang, waktu, serta keadaan (Maryam Jemeelah dkk, 1977: 42). 7). Penyembahan manusia dengan kedok ilmu pengetahuan, artinya, bahwa kemajuan ilmu pengetahuan pada akhirnya bisa memberikan kepada manusia terhadap semua kekuatan Tuhan (Maryam Jemeelah dkk, 1977: 40).

Berbagai ciri Modernisme di atas, tiada lain merupakan hasil refleksi dan kontemplasi hasil penemuan dalam al-bahts al-'llmi para sarjana dalam konteks kajian "Modernisme" tersebut.

\section{Fundamentalisme: Akar Histories dan Karakteristik}

Isu-isu "Fundamentalisme" yang berkembang di masyarakat masih dalam ruang lingkup payung protestan di Amirika. Sebagai gerakan yang lahir dan muncul akibat kekecewaan terhadap gerakan pemikiran evangelical-liberalism atau sebagai embrio pemikiram Modernisme atau Liberalisme. Pernyataan ini, ternyata juga sejalan dengan gerakan pemikiran strick-conservatism (konservatisme ketat) yang dikomandani oleh Charles G. Finney, yang mengajak kepada pemikiran ortodok terdahulu.

Berangkat dari strick-concervatism, secara lebih singkat, telah dapat melahirkan lima pernyataan yang terkenal sebagaimana berikut : a). kepercayaan total akan Al-Kitab b) Ketuhanan Yesus c) Kelahiran dari seorang perawan d) Adanya penebusan dosa e) Kebangkitan Yesus kembali secara fisik nanti (the inerrancy of scripture in every respect, the deity of Jesus, the virgin brith, the subtiononery atonement, the physical resurrection and bodly return of Jesus Christ) (Robert Handy, 1955: 390). Berbagai poin tersebut itulah, merupakan teori yang cukup dikenal dengan sebutan lima poin fundamentalisme (the five points of fundamentalism). 
Perlu dicatat, bahwa pada tahun 1920-an gerakan "Fundamentalisme" pernah mencapai puncak kejayaan di Presbyterian daerah selatan USA, dan ia mampu menggusur atau menghapuskan kelompok Liberal, atau bahkan kelompok tersebut menjadi kelompok minoritas dalam dominasinya.

Sesungguhnya, antara kelompok strick-conservatism dan kelompok fundamentalism memiliki banyak persamaan, yang juga berarti perbedaan. Selanjutnya, pokok perbedaan inti di antara keduanya terpusat pada masalah spirit daripada perbedaan dasar teologis. Dua kelompok tersebut juga merujuk pada ekstensi teologis protestan or todox, namun fundamentalis lebih cenderung agresif, lebih intrasigen, lebih yakin bahwa mereka yang mempunyai semua kebenaran, sementara kelompok lain tidak memilikinya sama sekali. Fundamentalis tidak hanya secara militan menyatakan merupakan inspirasi al-Kitab, sementara kelompok lain salah bahkan tidak bisa. Pada dasarnya dua kelompok tersebut, bekerja sama dan berjuang dalam rangka untuk menjegal semakin lajunya arus paham Liberalisme dan Modernisme. (Robert Handy, 1955: 388). Selanjutnya, dalam peristiwa kesejarahan berikutnya, justru paham Liberlisme ini yang menjadi dominan, dan saat itulah sebagai kegagalan Fundamentalisme, yang tepat pada tahun 1930-an.

Persoalan yang mendasar dari uraian di atas, tada lain terdapat jurang pemisah dalam dikotomi faith (kepercayaan), dan reason (pikiran) pada sisi kelompok "Fundamentalisme", dan adanya saling keterkaitan dan saling melengkapi antara faith (baca: agama) dan reason (akal pikiran) difihak "Liberalisme" pada sisi yang lain. Pada tataran yang terakhir, setelah melalui proses peristiwa tersebut, selanjutnya dapat juga disebut sebagai "Modernisme Liberal".

Terakhir, karakteristik kelompok Fundamentalime dapat dijelaskan sebagaimana berikut : Pertama, oppositionalsm (paham perlawanan), artinya, gejala fundamentalisme dalam agama apapun senantiasa menunjukkan sikap perlawanan terhadap semua system yang dianggap dapat mengancam eksistensi agama, baik dalam bentuk modernitas maupun modernisme, sekulerisasi, dan bahkan semua nilai dan semua paham yang dklaim sebagai produk dan bercita rasa occident. Kedua, penolakan terhadap hermeniotika. 
Artinya, sikap ini ditunjukkan sebagai bentuk penolakan terhadap sikap kritis terhadap teks suci berikut interpretasi secara rasionalistik terhadapnya, serta menolak pemahaman teks keagamaan yang bercorak kontekstual dan histories. Ketiga, penolakan terhadap pluralisme dan relativisme. Artinya, kelompok ini memiliki suatu reaksi yang sangat kuat terhadap kelompok lain yang memiliki perbedaan dengan mereka. Keempat, penolakan terhadap perkembangan histories dan sosiologi. Artinya, kelompok ini seringkali mendistorsi sejarah dan realitas sosiologis, karena dihegemoni oleh romantisme, kendatipun cita-cita yang diidealkan terdapat pula sebagaimana yang telah ditemukan pada masa Nabi dan generasi Ulama Salaf (untuk tidak mengatakan mustahil) terwujudkan (Ama Noor Fikry, dalam Makalah, 2004:13-14).

Selanjutnya perlu diterangkan pula tentang berbagai penelitian terdahulu oleh para sarjana mengenai karakteristik "Fundamentalisme". Hal ini dapat pula dipertegas sebagaimana berikut : 1). Rigid-leteralis-fanatik, corak pendapat ini di wakili oleh Allan R. Taylor 2). Legalis-konservatif, corak pendapat ini diseponsori oleh Daniel Pipes 3). Anti intelektual, yang pendapat ini disponsori oleh Fazlur Rahman 4). Slogan revolosioner, pendapat yang terakhir ini ditegaskan oleh Hrair Dekmejian (Allan R. Taylor, 1988: viiii.).

Berbagai karakteristik yang di kemukakan diatas, merupakan hasil penelitian dari para sarjana, yang dapat dijadikan parameter untuk membedakan paham Fundamentalisme dengan berbagai aliran atau paham lain yang beragam. Pernyataan tersebut, menegaskan bahwa apabila terdapat karakteristik paham atau aliran tersebut tidak ditemukan dalam parameter yang telah ditentukan maka secara otomatis tidak dapat pula faham tersebut dimasukkan dalam kategori "Fundamentalisme", demikian pula sebaliknya.

\section{Modernisme dan Fundamentalisme: Korelasinya Idiologi dalam Pergerakan}

Dua istilah aliran tersebut merupakan sama-sama menggunakan dasar idiologi pergerakan mereka yang didasarkan al-Qur'an dan al-Hadits. Pengambilan dasar marja' tersebut apabila kita mengkaitkan dua idiologi termaktub dengan Islam. Apabila bergulirnya dua arus besar idiologi itu 
tidak dikaitkan dengan Islam, maka sesungguhnya, dua kelompok modernis maupun fundamentalis masuk dalam wilayah payung agama protestan di Amerika.

Persoalan yang perlu dikritisi sekarang, bahwa "Modernisme" dan "Fundamentalisme" itu dapat dipahami melalui cara berfikir (metodologi) yang terfokus dalam pola pemikiran lama berupa keyakinan ( $($ aith) yang di wakili oleh kaum track-conservatism (konservatisme ketat) dalam satu sisi, dan cara berfikir (metodologi) yang terfokus pada pola pemikiran alakekinian berupa penggabungan dan saling melengkapi antara keyakinan (faith) dan pikiran (reason) dalam sisi yang lain di fihak kaum Liberalisme. Namun demikian yang terjadi, terdapat ada-nya titik temu dalam kerangka pergerakan yang bertahan dalam track-concervatism adalah "Fundamentalisme", kemudian yang larut dan bertahan di "Liberalisme" adalah "Modernisme". Artinya, dua idiologi "Fundamentalisme" memiliki hubungan dengan "Modernisme" itu dalam konteks historisitas.

Dari sisi lain, memiliki kecenderungan dalam hubungannya dengan menafsirkan idiologi modernisme dan fundamentalisme yang saling bertolak belakang. Aliran pertama bersikap elastis dan fleksibel dan kedua, memiliki sikap rigid dan literalis. Akan tetapi pengklasifikasian yang dimaksud, memiliki korelasi yang signifikan dengan karakteristik-karakteristik dari berbagai masing kelompok modernis dan fundamentalis, atau bahkan perbedaan antara keduanya.

\section{Modernisme dan Fundamentalisme dalam Isu-Isu Sosial Masyarakat}

Isu-isu Sosial masyarakat sebagai fenomena yang berkaitan dengan Modernisme dan Fundamentalisme dapat dijelaskan dalam dua hal. 1) Modernisme sebagai fenomena gerakan social masyarakat 2) Fundamentalisme sebagai fenomena gerakan social masyarakat.

\section{I). Modernisme Sebagai Fenomena Gerakan Sosial Masyarakat}

Teori perubahan (konversi) yang diusung oleh berbagai aktivis pergerakan ternyata tidak dapat dipisahkan dengan orientasi idiologi 
pergerakan itu sendiri. Hal yang demikian ini, dapat digambarkan dari bentuk perubahan masyarakat konservatis-tradisionalis, ke reformismodemis atau sebaliknya, dari reformis-modernis, ke sekularis-modernis atau sebaliknya, dari reformis-modernis, ke puritanis-fundamentalis, atau dari sekularis-modernis, ke reformis-modernis atau puritanis-fundamentalis (Achmad Jaenuri, 2004: 65).

Namun demikian, pernyataan di atas, hanya salah satu tamtsilan yang akan dapat dijadikan pijakan dalam menggambarkan fenomena keagamaan dalam gerakan social masyarakat. Fenomena keagamaan tersebut hanya dimaksudkan terdapat dalam konversi masyarakat konservatif-tradisionalis ke masyarakat reformis-modernis. Pemetaan polarisasi masyarakat, paling minimal sangat juga dipengaruhi oleh orientasi idiologi gerakan yang dikembangkan, miskipun masih menurut Achmad Jaenuri idiologi itu sendiri bersifat tentative, akan selalu mengalami perubahan (Achmad Jaenuri, 2004: $65)$.

Berbagai isu gerakan thurats yang diwakili oleh kaum qadimis ke hadatsah yang diwakili oleh kaum jadidis juga telah mengundang reaksi menuju peta perubahan yang cukup signifikan di tengah masyarakat. Masyarakat yang mengalami iklim konversi tersebut dapat digambarkan sebagai contohnya, modernisasi dan pembaharuan (reformasi) Universitas Al-Azhar oleh Muhammad Abduh Mesir (Muhammad Al-Bahy 1987: 87), beliau mengadakan perubahan tersebut juga mendapat perlawanan keras oleh kelompok para Shaikh Al-Azhar yang memiiliki otoritas kuat dan kecenderungan dalam mempertahankan tradisi (nilai) yang ada. Demikian pula, juga muncul modernisasi dan pembaharuan Alligharh College di India yang digerakkan oleh Sayyid Akhmad khan (Maryam Jameelah dkk. 1977: 185.).

Dua tokoh yang digambarkan tersebut, merupakan tokoh reformismodernis yang tidak menolak berbagai gagasan dan ide (pemikiran) yang ditawarkan oleh Barat, miskipun harus mendapatkan perlawanan ketat oleh sejumlah tokoh pergerakan konservatif-tradisionalis yang cenderung menolak terhadap perubahan. Perkembanagan selanjutnya, banyak pembaharu-pembaharu yang bermunculan, seperti: Muhammad Rasyid Ridha, Ali Abdur Raziq, Muhammad Kurd, dan Thaha Husein dan lain- 
lain( Maryam Jameelah: Ibid). Demikian pula, terdapat para aktifis yang masuk dalam lingkaran Jaringan Islam Liberal (JIL) yang dikomandani oleh Ulil Abshor Abdalla dkk. Di Indonesia, yang juga tidak kalah dahsyatnya telah mendapatkan sorotan tajam dari berbagai fihak.

\section{2). Fundamentalisme Sebagai Fenomena Gerakan Sosial Masyarakat}

Fenomena gerakan social masyarakat yang dimaksudkan, dapat memasukkan reaksi pemahaman terhadap subtansi agama itu sendiri secara rigid-literis, sebagai akibat ketidakpuasan terhadap bergulir-nya isu-isu yan menyebabkan sebuah konversi perubahan orientasi idiologi pergerakan mereka dari reformis-modernis ke puritanis-fundamentalis.

Pernyataan di atas, dapat pula difragmentasikan sebagai gerakan jihad yang dimaknai oleh kelompok fundamentalis Mesir yang terwadahi dalam gerakan Ikhwanul Muslimin (IM) yang dikomandani oleh Hasan al-Banna dan diteruskan oleh Sayyid Qutub. Demikian pula, terdapat pergerakan Jamaat Islami (JI) di Pakistan yang dipimpin oleh al-Maududi, atau bahkan Hizbut Tahrir (HT) Internasional, termasuk yang marak berkembang di Indonesia (HTI). Pada dasarnya, pergerakan yang mereka usung setidaknya akan dapat melahirkan polarisasi dua makna jihad yang dapat ditandaskan sebagaimana berikut: 1) jihad berarti kulltural dan 2) jihad berarti structural. Oleh karena itu, pada perkembangan idiologi Jamaat Islami (JI) selanjutnya, telah memiliki motivasi yang sangat kuat di Pakistan dan Mindanao. Di samping dapat menghasilkan makna jihad yang beragam menurut pendapat para aktivis pergerakan dalam orientasi idiologi pergerakan mereka.

Dari sisi lain, perkembangan berbagai gerakan fundamentalis yang diperjuangkan sejumlah tokoh-tokoh diatas, ternyata juga dapat berimbas dan menjalar di kawasan Indonesia, lebih-lebih di kawasan Perguruan Tinggi Umum maupun Perguruan Tinggi Islam. Fenomena-fenomena ini dapat dijelaskan seperti: FPI, KISDI, KAMMI, MMI, HTI dan lani-lain. Sesungguhnya, mereka dalam pemahaman agama terkesan rigid-literalisekskhusif sedemikian rupa, sehingga menghasilkan dalam merespon tuntutan situasi dan kondisi yang senantiasa mengalami perubahan dan perkembangan yang sangat cepat juga melahirkan cara bersikap dan bertindak mereka yang reaksioner dan emosional atau bahkan radikal 
terhadap pandangan pemahaman agama yang berbeda dengan mereka. Pernyatan ini, dapat digambarkan sejumlah kasus yang di antaranya: penggrebekan lokasi-lokasi kemaksiatan beberapa tahun yang lalu di Jakarta, dan pemrotesan beberapa tayangan media-cetak maupun elektronik beberapa saat yang lalu, dan lain-lain. Menurut mereka, apa yang mereka perbuat sudah tidak menyimpang dengan pedoman yang ada dalam alQur'an maupun al-Hadith, dan mereka menganggap kasus-kasus yang bermunculan tersebut sangat amat merugikan umat Islam.

Terakhir, memahami masyarakat yang mengalami perubahan yang berkaitan dengan orientasi idiologi gerakan, setidaknya dapat didorong oleh dua faktor. Pertama, kesadaran indivindu seseorang akan perubahan karena pengetahuan yang dimilikinya. Kedua, perubahan dan perkembangan lingkungan yang terjadi dalam masyarakat memaksa seseorang, cepatatau lambat, menjawab tantangan yang muncul akibat perubahan itu (Achmad Jaenuri, 2004: 65).

Pemahaman dalam tingkat ilmu pengetahuan yang dimilikinya, berikut perubahan perkembangan lingkungan (situasi dan kondisi) yang kontinyu, akan dapat melahirkan reformulasi idiologi baru yang dijadikan pedoman dalam mengantisipasi perubahan yang berlangsung di tengah permukaan.

\section{Penutup}

Meruju' dari berbagai uraian di atas, pembehasan ini dapat dijelaskan sebagai rumusan sebagaimana berikut:

1). Karakteristik "Modernisme" dan "Fundamentaliusme" berakar dari historisitas akar kelahiran, pemikiran, kondisi dan situasi dalam social masyarakat, kendati isu-isu dua istilah "Modernisme" dan "Fundamentalisme" belum ada kata sepakat di antara kalangan para sarjana itu sendiri. Bertolak dari latar belakang masing-masing paham di atas, maka karakteristik "Modernisme" dan "Fundamentalisme" dapat di fragmentasikan sebagai berikut: pertama: : karakteritis "Modernisme" secara umum adalah : 1) kalkulasi (counting) 2) perbandingan (comparing) 3) sistematisasi 
(systematizing). Sedangkan karakteristik "Modernisme" secara khusus dalam pandangan para sarjana adalah : a) apologetik b) romantisme c) keharusan ijtihad d) jalan tengah e) penafsiran ijma' modernisme f) penolakan nilai-nilai transcendental g) penyembahan manusia dengan kedok ilmu pengetahuan. Kedua, karakteristik "Fundamentalis" dapat juga dijelaskan secara umum sebagaimana berikut: 1) oppotisionalism (paham perlawanan) 2) penolakan terhadap herminiotika 3) penolakan terhadap pluralisme dan relativisme 4) penolakan terhadap histories dan sosiologi. Sedangkan penjelasan khusus menurut para sarjana adalah : a) rigid-literis-fanatik b) ligalis-konservative c) anti intelektual d) slogan revolosioner.

2). Modernisme memiliki keterkaitan pra-Modernisme, sedangkan Fundamentalisme sebagai reaksi dari paham modernisasi, westernisasi, dan sekularisasi. Modernisme ada hubungannya dengan Fundamentalisme itu dalam tiga hal, pertama, memiliki marja' sama terhadap al-Qur'an dan al-Hadits. Pernyataan tersebut apabila dikaitkan dengan Islam kedua, dikotomi keyakinan (faith) dan pikiran (reason) ketiga, bertolak belakang paham aliran. Selanjutnya, kasus-kasus keagamaan dalam gerakan social masyarakat yang dapat dicontohkan masuk kategori "Modernisme"seperti: pergerakan pembaharuan dan modernisasi Al-Azhar Mesir oleh Muhammad Abduh, Allighath College di India oleh Sayyid Akhmad Khan yang membuka diri terhadap konsepkonsep Barat yang masuk, dan sejumlah tokoh lainnya pada satu sisi. Pada sisi yang lain, kasus-kasus yang dikategorikan "Fundamentalisme" seperti: Ikhwanul Muslimin (IM) Mesir oleh Hasan al-Banna, Jamaat Islami (JI) Pakistan oleh al-Maududi, HTI, KISDI, MMI, KAMMI, FPI, di Indonesia, dan lai-lain.

Demikian Uraian pembahasan ini, berbagai saran dan masukan dalam tulisan ini, sangatlah penulis harapkan. Akhirnya, semoga berguna dan bermanfaat. Wallahu 'Alam Bi al-Shawab 


\section{DAFTAR PUSTAKA}

Al-Bahy, Muhammad. Pemikiran Islam dan Modren. Jakarta: Pustaka Panji Mas, 1997.

Al-Sufy, 'Adb. Al-Qadir. Resurgent Islam 1400 Hijra. Norwich: Diwan Press, 1979.

A. R. Ghibb, Hamilton. Modren Trends in Islam. Chicago: The Chicago University, 1997.

Bannerman, Patrick. Islam And Prespective, A Guide to Islamic Society Politic and Law. London: Routletge, 1988.

Bender, Leonard. Religion and Politich in Pakistan. Berkeley and Los Angeles: The University of California Press, 1961.

Dekmejian Hrair. Islam in Revolution Fundamentalism. Syracus: Syracus University Press, 1985.

Fikry, Ama Nur. Akar Sejarah Fundamentalisme (Pertumbuhan dan Perkembangannya). Surabaya: Makalah PPS IAIN, 2004.

Gharaudy, R. Islam Fundamentalis dan Fundamentalis lainnya. Bandung: Penerbit Pustaka, 1993.

Hanafi, Hasan, dan Al-Jabiri, Muhammad 'Abid. Membunuh Syetan Dunia Meleburkan ke Timur dan Barat dalam Cakrawala Kritik dan Dialog. Terj. Bukhory Umari. Yogjakarta: IRCiSiD, 2003.

Handy, Robert T.. "Fundamentalism And Modemism in Prespective" dalam Religion Life. New York City: t.p., 1955.

Jameelah, Maryam. Islam And Modernism. Lahore: Islamic Publication, 1977. , Islam dan Modernism. Terj. A. Jaenuri dkk. Usaha Nasional, t.t.

Jaenuri, Achmad. "Tradisi dan Modernitas: Reevaluasi Polarisasi Makna Istilah" dalam Akademika Jumal Studi Keislaman. Vol. 15, No. I. Surabaya: Program Pascasarjana IAIN Sunan Ampel, September, 2002.

Jones Sidney. Motivasi Idiologis Aktivis JI Sangat Kuat. Liha dalam http: www.islamlib. Com/id/page.php?=article\&id

Lawrence, Bruce B.. Defenders Of God. San Fransisco: Hodper And Row, 1989. 
Mahendra, Yusril Ihza. Modernisme dan Fundamentalisme dalam Politik Islam. Jakarta: Paramadina, 1999.

Majid, Nurcholis. Islam: Doktrin dan Peradaban. Jakarta: Yayasan Wakaf Paramadina, 1992.

Pipes, Daniel. In The Path of God: Islam and Political Power. New York: Basic Book, 1983.

Rahman, Fazlur. Islam And Modernity, and Intellectual Transformation. Inneapolis: Bibliotheca Islamica, 1979. , Islam. Chicago: The University Press, 1982.

Smith, Wilfred C.. Modren Islam in India: A Social Analysis. New York: Russel and Russel, 1946.

Taylor, Allan R. The Islamic Question In Midle East Poitics. London: Westview, 1988.

The Encyclopedia Americana. Vol. 19. International Edition, 1970.

The Oxford English dictionary. Oxford, 1988 